\title{
BIOCHEMICAL COMPOUNDS FROM APRICOT LEAVES INVOLVED IN RESISTANCE TO MONILINIA SPP.
}

\author{
Cristina Petrisor ${ }^{1}$, Maria Dumitru ${ }^{2}$, Roxana Zaharia $^{1}$, Viorel Oltenacu ${ }^{2}$ \\ ${ }^{1}$ Research and Development Institute for Plant Protection Bucharest, Romania \\ ${ }^{2}$ Research and Development Station for Fruit Tree Growing Baneasa, Bucharest, Romania \\ *Correspondence address: \\ Research-Development Institute for Plant Protection \\ 8 Ion Ionescu de la Brad 013813, Bucharest, Romania \\ phone: 004-021-2693231 \\ fax: 004-021-2693239 \\ E-mail:crisstop@yahoo.com
}

http://www.doi.org/10.54574/RJPP.14.12

\begin{abstract}
Brown rot caused by Monilinia laxa is an important fungal disease of apricot (Prunus armeniaca) causing economical losses in different growing areas in Europe. M. laxa induces great damage in apricot, attacking flowers, leaves, stem, branches and fruits. The damage severity is strictly related to the climate conditions and several fungicide treatments are often necessary in order to limit the disease. Therefore, the aim of this study was to investigate the changes in the content of pigments (chlorophylls, carotenoids), total polyphenols, peroxidase, catalase, polyphenol oxidase in the leaves of the different apricot varieties. All these parameters were chosen taking in account their involvement in plant disease resistance. Concerning to chlorophylls and carotenoids level, less amounts were recorded in the leaves collected from the all symptomatic apricot varieties studied. Activities of peroxidase, catalase and polyphenol oxidase and total polyphenols were increased in the apricot samples affected by M. laxa compared with the healthy ones. Among the analyzed cultivars, Dacia, Litoral and Favorit showed a great tolerance to $M$. laxa. The genotypes like Carmela and Viorica showed different susceptibility.
\end{abstract}

Keywords: antioxidant enzymes, phenols, carotenoids, infected leaves.

\section{INTRODUCTION}

Monilinia spp. are a complex of pathogens which causes significant losses to pome fruits. Monilinia laxa (Aderhold and Ruhland) Honey and M. fructicola (G. Winter) Honey occur frequently on plum, cherry, apricot, peach, nectarine, cherry and sour cherry (Poniatowska et al., 2013; Rungjindamai et al., 2014; Martini \& Mari, 2014). Brown rot caused by $M$. laxa is one of the most important diseases in Prunus species grown in commercially orchards, inducing blossom wilt and twig blight in stone fruits, causing significant losses in production capacity of infected trees (Mari et al., 2003; Lino et al., 2016).

Some endogenous chemical compounds (ascorbate, phenols, carotenoids, carbohydrates) and various enzymes (peroxidases, catalases, glutathion reductase, polyphenoloxidase) play an important role in plant tolerance and self-protection against biotic factors. Infections cause changes in secondary metabolism by activating self-protection processes and altering primary metabolism, affecting plant growth and development (Swarbrick et al., 2006; Szugyi \& Sardi, 2018).

Numerous scientific reports suggest involvement of phenolic compounds and assimilation pigments in plant defense against different pathogens (Ivascu et al., 2002; Arun et al., 2010; Petrisor et al., 2012; Rasoulnia et al., 2018; Almatwari et al., 2020; Del Cueto et al., 2021). Previous work on resistance mechanisms to apple scab Venturia inaequalis (Cke.) Wint., has proven that the changes in phenolic compounds and enzymes between susceptible and resistant apple fruit cultivars are especially evident in the content of flavanols, phloridzin and hydroxycinnamic acids. Resistant apple cultivars have a higher content of hydroxycinnamic 
acids and flavanols compared with susceptible apple cultivars (Arici et al., 2014). A good correlation between level of phenolic in the leaves and resistance to pathogen attack was reported by Hassan et al. (2020).

Importance of antioxidant enzymes in resistance reactions have been reported for a range of crops and also in trees (Vanitha \& Umesha, 2008; Debona et al., 2012; Khodadadi et al., 2016; Hassan et al., 2020; Obi et al., 2020). These enzymes participate not only in phenol metabolism but also the formation and accumulation of some metabolites such as lignin and phytoalexin. Similarly, it has been reported that the presence of some preformed antifungal compounds, such as catechin and epicatechin, proved to be responsible for resistance against gray mold Botrytis cinerea in strawberries (Terry et al., 2004).

Results of Szugyi \& Sardi (2018) demonstrated that sour cherry genotypes with different levels of disease resistance could be clearly distinguished based on the monosaccharide (glucose + fructose) to sucrose ratio. The sucrose quantity had a significant effect on the level of resistance. Also, studies of Goncalves et al. (2005) showed that the carbohydrate contents in the leaves were increased in sugarcane infected with Sugarcane yellow leaf virus. They support that sucrose was the sugar that accumulated most in the leaves of infected plants, followed by total soluble sugars and reducing sugars.

The aim of this study was to investigate the photosynthetic pigments, total phenols and antioxidant enzymes involved in the defense mechanism of apricot leaves naturally affected by symptoms specific to brown rot.

\section{MATERIALS AND METHODS}

Leaves samples with natural symptoms of the brown rot from five apricot cultivars with early ripening (Dacia, Carmela and Viorica) and late ripening (Litoral and Favorit) were collected from the orchards of the Research-Development Station for Tree Fruit Growing Baneasa, Bucharest (Figure 1).
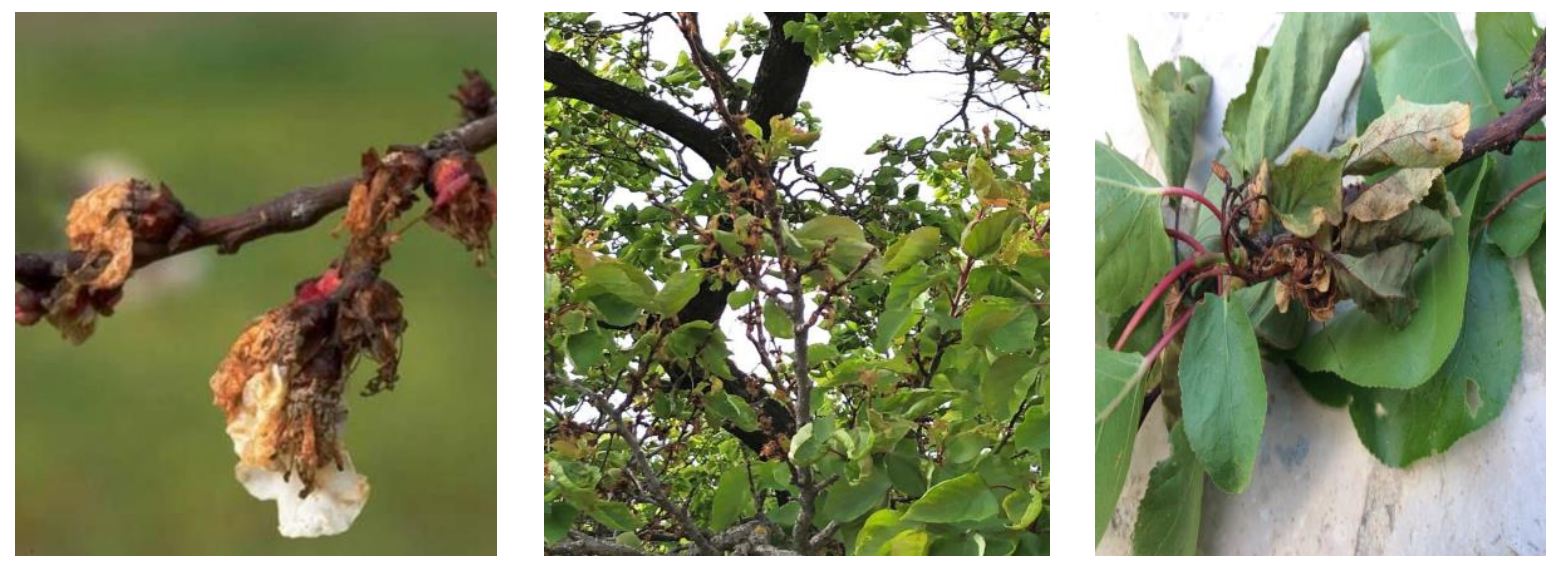

Figure 1. Monilinia laxa infection on apricot tree

Chlorophyll (Chl a, b) and total carotenoid (Car) were determined and calculated according to Lichtenthaler \& Wellburn (1985) method. In brief, leaves' photosynthetic pigments were extracted with $80 \%(\mathrm{v} / \mathrm{v})$ acetone in presence of calcium carbonate. Extracts were centrifuged at $5000 \mathrm{rpm}$ for 15 minutes and the absorbance of the supernatant was measured at 663, 646 and $470 \mathrm{~nm}$ with a UV-VIS spectrophotometer. Chlorophyll and carotenoid contents were calculated by specific formulas and results were expressed as mg/L. Total phenolic content of extracts was determined using the Folin-Ciocalteu method (Singleton 
\& Rossi, 1965) with three replicates. The content of phenolic compounds was determined both in healthy and infected tissue with Monilinia sp. The absorbance was measured at $725 \mathrm{~nm}$, with UV-VIS spectrophotometer. Results are expressed as GAE mg/g fresh weight [FW]).

To assay enzymes activity, fresh tissue from infected and healthy leaves was homogenized in an ice cooled mortar in $100 \mathrm{mM}$ Potassium-phosphate buffer, $\mathrm{pH} 7.0$ containing $1 \%$ soluble PVP and $1 \mathrm{mM}$ EDTA. The homogenate was centrifuged at $10000 \mathrm{~g}$ for $15 \mathrm{~min}$ and the supernatant was passed through a $0.45 \mu \mathrm{m}$ filter and used for assay of the antioxidant enzymes activity. Catalase (CAT) activity was measured according the method of Beers \& Sizer (1952). The peroxidase (POX) activity was estimated according to the method of Hammerschmidt et al., (1982) using guaiacol as the substrate. Polyphenol oxidase (PPO) was determined according to the method described by Mayer et al. (1966).

\section{RESULTS AND DISCUSSIONS}

This study was conducted to investigate the changes in the antioxidant enzymes activity and non-enzymatic compounds content of five apricot varieties against $M$. laxa infection in order to understand the biochemical tolerance mechanism of apricot. Our results showed that apricot varieties respond differently to a fungal infection, based on their susceptibility or resistance to disease. Under stressful conditions, such as fungal infection produced by $M$. laxa, activation of biochemical parameters plays a vital role in the defense mechanism.

The concentration of the most abundant plant pigments, $\mathrm{Chl} \mathrm{a,} \mathrm{Chl} \mathrm{b,} \mathrm{Chl} \mathrm{a/Chl} \mathrm{b} \mathrm{ratio}$ and Car are summarized in the Table 1. In all apricot cultivars leaves affected by M. laxa symptoms, there is a decrease in the content of total chlorophyll and total carotenoids, compared to unaffected varieties. In the most strongly affected varieties by brown rot (Viorica and Carmela), the chlorophyll content had a more pronounced decrease than the tolerant ones. Similar results have been reported by Ivascu et al., (2002). The $\mathrm{Chl}$ a/ Chl b ratio, which is used as stress indicator, was increased in symptomatic leaves for all apricot cultivars studied. Our results show that Car/Chl ratio increased in leaves affected by symptoms of all cultivars studied. These results are in agreement with the findings of Zafari et al., (2012).

Table 1. Variation of physiological parameters in apricot leaves - healthy and infected with M. laxa

\begin{tabular}{|l|c|c|c|c|c|c|c|}
\hline \multirow{2}{*}{ Cultivar } & $\begin{array}{c}\text { Leaves } \\
\text { status }\end{array}$ & $\begin{array}{c}\text { Chl a } \\
(\mathrm{mg} / \mathrm{L})\end{array}$ & $\begin{array}{c}\text { Chl b } \\
(\mathrm{mg} / \mathrm{L})\end{array}$ & $\begin{array}{c}\text { Chl(a }+\mathrm{b}) \\
(\mathrm{mg} / \mathrm{L})\end{array}$ & $\begin{array}{c}\text { Chl a / } \\
\text { Chl b }\end{array}$ & $\begin{array}{c}\text { Car } \\
(\mathrm{mg} / \mathrm{L})\end{array}$ & $\begin{array}{c}\text { Car/Chl } \\
(\mathrm{a}+\mathrm{b})\end{array}$ \\
\hline \multirow{2}{*}{ Dacia } & Healthy & 46.89 & 10.80 & 67.9 & 4.34 & 13.20 & 0.19 \\
\cline { 2 - 8 } & Infected & 42.3 & 9.10 & 51.40 & 4.64 & 12.33 & 0.23 \\
\hline \multirow{2}{*}{ Viorica } & Healthy & 32.69 & 11.66 & 44.35 & 2.80 & 8.69 & 0.19 \\
\cline { 2 - 8 } & Infected & 27.3 & 7.9 & 35.2 & 3.45 & 7.95 & 0.22 \\
\hline \multirow{2}{*}{ Carmela } & Healthy & 54.40 & 11.34 & 65.74 & 4.80 & 14.55 & 0.22 \\
\cline { 2 - 8 } & Infected & 45.51 & 9.20 & 54.72 & 4.94 & 12.83 & 0.23 \\
\hline \multirow{2}{*}{ Favorit } & Healthy & 45.88 & 11.73 & 67.61 & 4.16 & 11.18 & 0.16 \\
\cline { 2 - 8 } & Infected & 43.39 & 10.25 & 53.64 & 4.23 & 9.42 & 0.17 \\
\cline { 2 - 8 } & Healthy & 29.50 & 10.90 & 40.40 & 2.70 & 8.40 & 0.20 \\
\hline
\end{tabular}

Infected plants show a high content of phenols, which could be due to both of the activation of the host defense mechanism and the pathogen attack mechanism (Arun et al., 2010). The results of the present study showed that higher level of total phenols was found in the infected apricot cultivars leaves compared to those of healthy cultivars. Also, the quantity of total phenols is in lower in uninfected tissue of Carmela and Viorica compared to Dacia, Litoral and Favorit that have a higher phenols content in healthy leaves. The increase in total phenols content in apricot after infection with M. laxa has also been demonstrated by Del Cueto 
et al., 2021 studies, which showed that phenols content is higher in apricot branches infected by $M$. laxa than in healthy ones. Also, other researchers have shown a significantly higher content of total phenols, total flavonoids and tannins in asymptomatic leaves of persimmom (Dyospiros kaki) cultivars affected by Plurivorosphaerella nawae fungus, compared with symptomatic leaves (Hassan et al., 2020). However, Obi et al., 2020 supported that besides the phenolics, neither ascorbate nor glutathione or carotenoids have ever been considered in conferring tolerance to brown rot in peach.

Phenolic compounds such as caffeic acid and chlorogenic acid, have been shown to inhibit the production of cell wall degrading enzymes (cutinases and polygalacturonases) by $M$. fructicola, and these may play a role in reducing the infectivity of $M$. fructicola. There is also some evidence (Lee \& Bostock, 2007) that these phenolics may inhibit appressorial formation.

Table 2. Variation of antioxidant enzyme and total phenols in apricot leaves healthy and infected with brown rot

\begin{tabular}{|l|c|c|c|c|c|}
\hline Cultivar & $\begin{array}{c}\text { Leaves } \\
\text { status }\end{array}$ & $\begin{array}{c}\text { Peroxidase } \\
\text { U/min/mg } \\
\text { protein }\end{array}$ & $\begin{array}{c}\text { Catalase } \\
\text { U/min/mg } \\
\text { protein }\end{array}$ & $\begin{array}{c}\text { Polyphenol } \\
\text { oxidase } \\
\text { U/min/g F.W. }\end{array}$ & $\begin{array}{c}\text { Total phenols } \\
\text { mg/g F.W. }\end{array}$ \\
\hline \multirow{2}{*}{ Dacia } & Healthy & 300 & 7.60 & 0.14 & 2.89 \\
\cline { 2 - 6 } & Infected & 545 & 14.6 & 0.30 & 3.90 \\
\hline \multirow{2}{*}{ Viorica } & Healthy & 88 & 6.6 & 0.16 & 1.55 \\
\cline { 2 - 6 } & Infected & 134 & 8.6 & 0.18 & 2.95 \\
\hline \multirow{2}{*}{ Carmela } & Healthy & 100 & 5.8 & 0.48 & 1.82 \\
\cline { 2 - 6 } & Infected & 167 & 10.7 & 1.35 & 3.73 \\
\hline \multirow{2}{*}{ Litoral } & Healthy & 115 & 9.5 & 0.20 & 2.97 \\
\cline { 2 - 6 } & Infected & 296 & 19.8 & 0.65 & 3.78 \\
\hline \multirow{2}{*}{ Favorit } & Healthy & 199 & 7.34 & 0.24 & 2.85 \\
\cline { 2 - 6 } & Infected & 421 & 22.6 & 0.65 & 3.95 \\
\hline
\end{tabular}

Antioxidant enzymes are produced by host plant to promote cells protection from oxidative damage caused by pathogens and thus inducing resistance against pathogen (Hernandez et al., 2006). Our results showed that the activity of antioxidant enzymes such as polyphenol oxidase, peroxidase and catalase was increased in the leaves affected by brown rot in all apricot varieties studied (Table 2). However, the response to infection was different depending on cultivar and enzyme. The activity of peroxidase in the leaves affected by M. laxa was doubled, compared to the value of the control in Dacia, Litoral and Favorit cultivars.

Catalase activity increased 2-fold in three of the studied apricot varieties affected by brown rot except for Favorit, where the activity of this enzyme is much more intense compared to the healthy variety. Similar results have been reported by Siddique et al. (2014) which showed that PAL, POD, CAT and SOD have active roles in disease resistance against Cotton Leaf Curl Burewala Virus in different varieties of cotton. PPO may play an important role in defense and inhibition of disease in infected cultivars, because a higher PPO activity can enhance resistance to phytopathogen attack. Our results showed a little increase of PPO in leaves of infected apricot cultivars with $M$. laxa. In conclusion, the present results regarding antioxidant enzymes suggest that brown rot infection is accompanied by oxidative stress.

\section{CONCLUSIONS}

The amount of chlorophylls and carotenoids has been significantly reduced in the leaves of apricot cultivars with symptoms specific to brown rot, in both early maturation and late maturation ones. 
The symptomatic leaves had a higher concentration of total phenols compared to the leaves of healthy cultivars.

The enzymatic activity of peroxidase, catalase and polyphenol oxidase was increased in apricot varieties showing symptoms of brown rot, compared to healthy varieties.

We can support that in the case of apricots, the content of total phenols and the activity of antioxidant enzymes in healthy varieties can be associated with resistance to brown rot.

Dacia, Litoral and Favorit cultivars showed a great resistance to M. laxa. The genotypes like Carmela and Viorica showed different susceptibility to $M$. laxa.

\section{REFERENCES}

ALMATWARI, A.H.A., HASSANDOKHT, M., SOLTANI, F., GOHARI, A.M., JAVAN-NIKKHAH, M. (2020). Biochemical defense responses of tolerant and susceptible lettuce accessions following infection by Sclerotinia sclerotiorum. Archives of Phytopathology and Plant Protection, 54, 13-14, 903907. doi:10.1080/03235408.2020.1869385

ARICI, S.E., KAFKAS, E., KAYMAK, S., KOC, N.K. (2014). Phenolic compounds of apple cultivars resistant or susceptible to Venturia inaequalis. Pharmaceutical Biology, 52, 7, 904-908.

ARUN, K., MALI, P.C., MANGA, V.K. (2010). Changes of some phenolic compounds and enzyme activities on infected pearl millet caused by Sclerospora graminicola. International Journal of Plant Physiology and Biochemistry, 2, 6-10.

BEERS, R.F., SIZER, I.W. (1952). A spectrophotometric method for measuring breakdown of hydrogen peroxide by catalase. Journal of Biological Chemistry, 195,133-140.

DEBONA, D., RODRIGUEZ, F.A., RIOS, J.A., NASCIMENTO, K.J.T. (2012). Biochemical changes in the leaves of wheat plants infected by Pyricularia oryzae. Phytopathology, 102, 12, 1121-1129.

DEL CUETO, J., CAGNAZZO, A.K., STEFANI, P., HERITIER, J., ROCH, G., OBERHANSLI, T., AUDERGON, J.M., CHRISTEN, D. (2021). Phenolic compounds identified in apricot branch tissues and their role in the control of Monilinia laxa growth. Scientia Horticulturae, 275, 10.1016/j.scienta.2020.109707.

GONCALVES, M.C., VEGA, J., OLIVEIRA, J.G., GOMES, M.M.A. (2005). Sugarcane yellow leaf virus infection leads to alterations in photosynthetic efficiency and carbohydrate accumulation in sugarcane leaves. Fitopatologia Brasileira, 30, 10-16.

HAMMERSCMIDT, R., NUCKLES, E.M., KUG, J. (1982). Association of enhanced peroxidase activity with induced systemic resistance of cucumber to Colletotrichum I'agenarium. Physiological Plant Pathology, 20, 73-82.

HASSAN, O., CHANG, T., HOSSAIN, A. (2020). Changes in secondary compounds of persimmom leaves as a defense against circular leaf spot caused by Plurivorosphaerella nawae. PLoS ONE, 15, 3, 1-17.

HERNANDEZ, J.A., DIAZ-VIVANCOS, P., RUBIO, M., OLMOS, E., ROS-BARCELO, A., MARTINEZ-GOMEZ, P. (2006). Long-term plum pox virus infection produces an oxidative stress in a susceptible apricot, (Prunus armeniaca), cultivar but not in a resistant cultivar. Physiologia Plantarum, $126,140-152$.

IVASCU, A., BALAN, V., PETRISOR, C., LAZAR, V., TOMA, S. (2002). Evaluation of some biochemical compounds implicated in biotic stress at some peaches and nectarines genotypes. XXVI International Horticultural Congress, Toronto, Canada, August 22-27.

KHODADADI, F., TOHIDFAR, M., MOHAYEJI, M., DANDEKAR, A.M., LESLIE, C.A., KLUEPFEL, D.A., VAHDATI, K. (2016). Induction of polyphenol oxidase in walnut and its relationship to the pathogenic response to bacterial blight. Journal of the American Society for Horticultural Science, 141, 2, 119-124.

LEE, M.H., BOSTOCK, R.M. (2007). Fruit Exocarp phenols in relation to quiescence and development of Monilinia fructicola infections in Prunus spp.: A role for cellular redox? Phytopathology, 97, 3, 269277. 
LICHTENTHALER, H.K., WELBURN, A.R. (1985). Determination of total carotenoids and chlorophyll $a$ and $b$ of leaf extracts in different solvents. Biochemical Society Transactions, 11, 591592.

LINO, L.O., PACHECO, I., MERCIER, V., FAORO, F., BASSI, D., BORNARD, I., QUILOTTURION, B. (2016). Brown Rot Strikes Prunus Fruit: An Ancient Fight Almost Always Lost. Journal of Agricultural and Food Chemistry, 64, 4029-4047.

MARI, M., CASALINI, L., BARALDI, E., BERTOLINI, P., PRATELLA, G.C. (2003). Susceptibility of apricot and peach fruit to Monilinia laxa during phenological stages. Postharvest Biology and Technology, 30,105-109.

MARTINI, C., MARI, M. (2014). Monilinia fructicola, Monilinia laxa (Monilinia Rot, Brown Rot). In (ed. Silvia Bautista-Baños) Postharvest Decay: Control Strategies, 233-265, Elsevier.

MAYER, A.M, HAREL, E., BEN-SHAUL, R. (1966). Assay of catechol oxidase a critical comparison of methods. Phytochemistry, 5, 783-789.

OBI, V.I., MONTENEGRO, J., BARRIUSO, J.J., SAIDANI, F., AUBERT, C., GOGORCENA, Y. (2020). Is the tolerance of commercial peach cultivars to brown rot caused by Monilinia laxa modulated by its antioxidant content? Plants, 9, 589; doi: 10.3390/plants9050589.

PETRISOR, C., BARBUlESCU, A., CAMPEANU, G., BALAN, V. (2012). Physiological and biochemical changes of apricot and peach cultivars PPV infected and PPV free. Acta Horticulturae, 940, 309-313.

PONIATOWSKA, A., MICHALECKA, M., BIELENIN, A. (2013). Characteristic of Monilinia spp. fungi causing brown rot of pome and stone fruits in Poland. European Journal of Plant Pathology, 135, 855-865.

RASOULNIA, A., ALAVI, S.M., ASKARI, H., FARROKHI, N., NAJAFABADI, M.S. (2018). Effects of Xanthomonas citri subsp. citri infection on chlorophyll pigment content, chlorophyll fluorescence and proteins change in Citrus aurantifolia. Journal of Agricultural Science and Technology, 20, 571582.

RUNGJINDAMAI, N., JEFFRIES, P., XU, X. M. (2014). Epidemiology and management of brown rot on stone fruit caused by Monilinia laxa. European Journal of Plant Pathology, 140, 1-17.

SIDDIQUE, Z, AKHTAR, K.P., HAMEED, A., SARWAR, N., IMRAN, U.H., KHAN, SA. (2014). Biochemical alterations in leaves of resistant and susceptible cotton genotypes infected systemically by Cotton leaf curl Burewala virus. Journal of Plant Interaction, 9, 1,702-711.

SINGLETON, V.L., ROSSI, J.A. (1965). Colorimetry of total phenolic with phosphomolybdic phosphotungstic acid reagents. American Journal Enology and Viticulture, 16, 144-158.

SZUGYI, S., SARDI, E. (2018). Connection between the disease resistance of sour cherry genotypes and the carbohydrate content of the leaf and phloem tissues. Horticultural Science (Prague), 45, 4, 181 186.

SWARBRICK, P.J., SCHULZE-LEFERT, P., SCHOLES, J.D. (2006). Metabolic consequences of susceptibility and resistance in barley leaves challenged with powdery mildew. Plant Cell and Environment, 29, 1061-1076.

TERRY, L.A., JOICE, D.C., ADIKARAM, N.K.B., KHAMBAY, P.S.B. (2004). Preformed antifungal compounds in strawberry fruit and flower tissues. Postharvest Biology and Technology, 31, 2, 201-212. VANITHA, S.C., UMESHA, S. (2008). Variations in defense related enzyme activities in tomato during the infection with bacterial wilt pathogen. Journal of Plant Interactions, 3, 4, 245-253.

ZAFARI, S., NIKAM, V., MUSETTI, R., NOORBAKHSH, S.N. (2012). Effect of phytoplasma infection on metabolite content and antioxidant enzyme activity in lime (Citrus aurantifolia). Acta Physiologiae Plantarum, 34, 2, 561-568. 